\title{
KORELASI PILKADA LANGSUNG DAN KORUPSI DI INDONESIA
}

\author{
Oleh : \\ Mulida Hayati, S.H, M.H \\ Rico Septian Noor, S.H, M.H \\ Fakultas Hukum Universitas Palangka Raya
}

\begin{abstract}
Abstrak:
Pemilu merupakan sebuah momen yang begitu penting di dalam sebuah negara Demokrasi seperti Indonesia. Dengan berbagai pengalaman menyelenggarakan pemilu sejak negara ini merdeka sampai pada perhelatan pemilu yang digagas secara langsung dan serentak sebagaimana amanat Mahkamah Konstitusi Republik Indonesia pada Putusannya. Begitu banyak persoalan di dalamnya, tak terkecuali Korupsi dalam praktik Pemilihan Umum Kepala Daerah Langsung di Indonesia. Penulisan ini mencoba menguraikan berbagai peluang terjadinya Korupsi di pelaksanaan Pilkada Langsung dan berbagai upaya yang dapat dilakukan guna mencegah Korupsi tersebut. Penulisan ini menggunakan metode Peneltian hukum Normatif dengan mengkaji persoalan secara normatif dengan menggunakan pendekatan konsep (Conseptual Approach). Secara umum kesimpulan dari hasil penulisan melihat bahwa korelasi Pilkada langsung dan Korupsi dalam hal berbagai kepentingan baik dari proses awal sampai pada Tahapan pelaksanaan Pilkada yang memerlukan biaya besar sehingga juga diperlukan komitmen dan Sinergitas yang kuat dari seluruh entitas di Negara ini agar persoalan Korupsi khususnya dalam Pilkada dan setelah Tahapan Pilkada selesai dapat dicegah.
\end{abstract}

Kata Kunci : Pilkada; Langsung; Korupsi

\section{Abstract:}

Elections are a very important moment in a democratic country like Indonesia. With a variety of experiences holding elections since the country gained its independence to the electoral event which was initiated directly and simultaneously as mandated by the Constitutional Court of the Republic of Indonesia in its Decision. There are so many problems in it, including Corruption in Direct Local Election practices in Indonesia. This writing tries to describe the various opportunities for Corruption in the implementation of the Direct Local Election and various efforts that can be made to prevent such Corruption. There needs to be a strong commitment and synergy from all entities in this country so that the problem of corruption is not widespread and rooted in Indonesia.

Keywords : Election, Direct, Corruption

\section{PENDAHULUAN}

Gerakan reformasi yang digelorakan di Indonesia pada Tahun 1998 telah membawa perubahan dalam berbagai aspek di Indonesia. Di bidang pemerintahan misalnya, sistem pemerintahan daerah mengalami perubahan signifikan dibandingkan era sebelum reformasi atau pada saat era orde lama dan orde baru. Sebagaimana yang sedang menjadi tren global, kebijakan desentralisasi juga dipilih dan 
diadopsi oleh Indonesia. Desentralisasi secara teoritis memang dinilai memberikan banyak nilai positif (Dennis et al., 1984).

Tuntutan reformasi di Indonesia salah satunya berhasil melahirkan Undang- Undang Nomor 22 tahun 1999 tentang Pemerintahan Daerah. Hingga saat ini revisi peraturan perundang-undangan mengenai pemerintahan daerah telah berulangkali mengalami perubahan, dan terakhir sistem pemerintahan daerah diatur melalui Undang-Undang Nomor 9 Tahun 2015 tentang Perubahan Kedua atas Undang-undang Nomor 23 Tahun 2014 tentang Pemerintahan Daerah. Meski sejak Tahun 1999 peraturan perundangundangan telah mengalami berbagai perubahan, namun arah dan semangat dasar pengaturan pemerintahan daerah tidak mengalami perubahan, yakni masih menganut desentralisasi dengan penekanan pada local democracy model (Suharto et al., 2017).

Konsekuensi strategis dari implementasi kebijakan desentralisasi tersebut ialah diberlakukannya model pemilihan pejabat politik (kepala daerah) yang demokratis. Sebagaimana amanat Konstitusi Pada Pasal 18 Ayat (4). Terjadi perubahan sistem pemilihan kepada daerah (Pilkada) dari yang tak langsung menjadi langsung. Kehendak agar pilkada digelar secara langsung akhirnya memang terwujud. Secara umum pilkada langsung yang telah dilaksanakan adalah salah satu bentuk dari perwujudan kedaulatan rakyat. Ada lima pertimbangan penting penyelenggaraan pilkada langsung bagi perkembangan demokrasi di Indonesia (Mubarok, 2005), yaitu:

Pertama, pilkada langsung merupakan jawaban atas tuntutan aspirasi rakyat karena pemilihan presiden dan wakil presiden, DPR, DPD, bahkan kepala desa selama ini telah dilakukan langsung. Kedua, pilkada langsung merupakan perwujudtan konstitusi dan UUD 1945. Ketiga, pilkada langsung sebagai sarana pembelajaran demokrasi (politik) bagi rakyat (civil education). Ia menjadi media pembelajaran praktik berdemokrasi bagi rakyat yang diharapkan dapat membentuk kesadaran kolektif segenap unsure bangsa tentang pentingnya memilih pemimpin yang benar sesuai nuraninya. Keempat, pilkada langsung sebagai sarana untuk memperkuat otonomi daerah. Keberhasilan otonomi daerah salah satunya 
juga ditentukan oleh pimpinan lokal yang dihasilkan dalam pilkada langsung 2005, maka komitmen pemimpin lokal dalam mewujudkan tujuan otonomi daerah, antara lain untuk meningkatkan kesejahteraan masyarakat dengan selalu memperhatikan kepentingan dan aspirasi masyarakat agar dapat diwujudkan. Kelima, pilkada langsung merupakan sarana penting bagi proses kaderisasi kepemimpinan nasional.

Kelima pertimbangan penting di atas menjadi dasar mengapa penyelenggaraan pilkada langsung tetap dilakukan. Pemilihan kepala daerah secara langsung memberikan optimisme kepada publik dan diharapkan akan membaiknya kualitas kepemimpinan baik di pusat maupun di tingkat daerah. Sekalipun dalam beberapa persoalan mengundang kekhawatiran masyarakat, namun mekanisme pemilihan pemimpin yang dipilih secara langsung oleh rakyat ini diyakini lebih baik dibandingkan dengan mekanisme pemilihan tidak langsung yang selama ini dilakukan (Mubarok, 2005).

Tetapi sungguh ironis, Pilkada langsung yang diharapkan mampu mewujudkan (setidaknya) lima pertimbangan di atas, pada sisi lain justru melahirkan yang sebaliknya. Munculnya berbagai persoalan termasuk salah satunya persoalan korupsi pada proses Pemilu yang telah membuktikan bahwa Pilkada langsung juga membawa sisi negative dapat dilihat dari berbagai kasus Kepala Daerah yang ditangkap KPK Karena Korupsi. Memaknai korupsi sendiri dalam bahasa Latin disebut Corruptiocorruptus, dalam Bahasa Belanda disebut corruptie, dalam Bahasa Inggris disebut corruption, dan dalam Bahasa Sansekerta yang tertuang dalam Naskah Kuno Negara Kertagama arti harfiah corrupt menunjukkan kepada perbuatan yang rusak, busuk, bejad, tidak jujur yang disangkut pautkan dengan keuangan (Hamzah, 2014). Fenomena korupsi di Indonesia sudah semakin memprihatinkan. Gejala dan perbuatannya terus meningkat dari tahun ke tahun, dari segi kualitas tindak pidana yang dilakukan semakin sistematis serta masuk ke seluruh lapisan struktur birokrasi, baik pemerintah maupun swasta. Sedangkan jumlah kerugian keuangan negara akibat perbuatan tindak pidana korupsi juga semakin bertambah besar. Keterpurukan perekonomian diyakini sebagai resultan dari adanya tindak pidana korupsi yang sistematis dan meluas (Nasional, 2014). Terutama yang dilakukan oleh pejabat 
pada badan publik baik di tingkat pusat maupun di tingkat daerah. Sistematisnya tindak pidana korupsi sebagai bagian kejahatan terstruktural yang sangat utuh terakar, kuat dan permanen sifatnya, sehingga korupsi sudah menjadi bagian dari sistem yang ada. Dalam praktiknya, Korupsi pemilu terdiri atas tiga (Zulkarnain, 2010), yaitu :

Pertama, penerimaan dana kampanye yang berasal dari sumber-sumber yang dilarang oleh peraturan perundangundangan maupun yang secara universal merupakan sesuatu yang secara nyata-nyata dianggap tidak boleh, karena menciptakan hubungan koruptif antara yang disumbang dan donatur.

Kedua, penyalahgunaan fasilitas negara dan jabatan untuk keperluan atau tujuan kampanye (abuse of power). Bentuk penyalahgunaan jabatan ini bisa macam-macam, mulai yang paling sederhana sampai ke kategori korupsi menurut Undang- Undang Tindak Pidana Korupsi. Misalnya, menggunakan kendaraan dinas untuk keperluan kampanye, mengerahkan Pegawai Negeri Sipil (ASN) atau bawahan (camat, lurah, pamong desa) untuk mendukung peserta pemilu tertentu, menyusun program populis seperti pembagian uang tunai (Money Politic) kepada kelompok masyarakat tertentu pada menjelang dan saat kampanye hingga penggunaan dana APBD/APBN untuk pembiayaan kampanye.

Ketiga, pembelian suara (money politics). Jika dikaitkan dengan isu dana kampanye, politik uang adalah bentuk ilegal dari pengeluaran dana kampanye. Artinya, dana kampanye peserta pemilu digunakan untuk kepentingan membeli suara pemilih maupun mempengaruhi penyelenggara pemilu untuk memanipulasi hasil pemilu, sesuatu yang sangat dilarang oleh UU Pemilu. Politik uang (money politics) akhir-akhir ini menjadi senjata utama sebagian politikus untuk mewujudkan ambisi politiknya. Uang tampaknya menjadi faktor yang paling dominan, modusnya bermacam-macam. Mulai dari yang paling halus, seperti bantuan untuk rumah-rumah ibadah, sumbangan di kegiatan keagamaan, bantuan duka, dan bantuan tak terduga. Yang semi halus, berupa investasi memenangkan pemilihan di tingkat desa, bantuan pendidikan, bantuan pembuatan jalan, bantuan bibit, juga penyaluran raskin. Yang kasar, berupa uang dan beras menjelang pemilihan.

Proses politik dalam pelaksanaan Pilkada tidak akan steril dari praktikpraktik kotor (korupsi), yaitu seperti kemungkinan adanya sumbangan politik secara ilegal (Illegal Political Contribution) kepada calon kepala daerah (Cakada) sudah merupakan salah satu bentuk dari praktik korupsi. Bukan rahasia umum lagi bahwa Pilkada langsung berimplikasi kepada persoalan dana, baik kebutuhan untuk anggaran pemerintah dalam membiayai Pilkada maupun biaya politik 
yang harus ditanggung para calon yang akan berkontestasi dalam Pilkada misalnya. Dari posisi pemerintah, Pilkada menghabiskan anggaran yang cukup besar. Anggaran yang semula harusnya dapat digunakan untuk keperluan pembangunan daerah akhirnya harus digunakan untuk membiayai Pilkada dengan perkiraan anggaran yang jumlahnya tidak sedikit. Terlebih lagi dengan adanya perubahan aturan Pilkada dimana dana kampanye dialokasikan oleh pemerintah daerah.

Pelaksanaan Pilkada juga menyerap biaya politik yang tidak kalah besar bagi calon. Dalam proses meraih dukungan partai politik dan rakyat, calon membutuhkan biaya yang tidak sedikit, sehingga hanya calon yang mempunyai dana dan akses besar yang dapat mengikuti kontestasi demokrasi dalam Pemilu ini. Peluang ini biasanya hanya dapat dimanfaatkan para incumbent, pengusaha dan segelintir elit politik yang dekat dengan kekuasaan. Ketigaya memiliki peluang besar dalam memenangkan Pilkada karena memiliki modal baik material, dukungan politik dan kekuasaan. Kebutuhan biaya besar yang diperlukan calon untuk maju dan memenangkan kompetisi Pilkada sering dianggap menjadi salah satu sebab maraknya korupsi, kolusi, nepotisme
(KKN) oleh kepala daerah.

Data hasil rilis Komisi Pemberantasan Korupsi (KPK) bahkan dari Tahun 2004 saja hingga November 2019 terhadap 139 kasus korupsi yang ditangani, 121 perkara melibatkan kepala daerah yang sebagian besar hasil dari OTT(Operasi Tangkap Tangan). Hal ini menandakan bahwa korupsi telah menjadi bahaya laten yang tidak bisa terbantahkan bahkan dalam pelaksanaan Pilkada sekalipun. Praktik korupsi yang massif terjadi, menunjukkan kegagalan pemimpin dan system dalam pemerintahan dalam menjalankan amanahnya dan membangun tata kelola pemerintahan yang bersih (Clean and Good Governance) (Hayati, 2020).

Penyebab dari korupsi kepala daerah, ternyata dipicu oleh transaksi suap yang masih tinggi di daerah. Para kepala daerah disinyalir harus mengembalikan modal kepada cukong untuk mengganti pembiayaan yang digunakan pada saat pilkada sebagaimana diketahui bahwa konsep Pilkada langsung memerlukan biaya dan modal yang besar. Lebih mirisnya lagi, beberapa calon kepala daerah dipilkada sebelumnya yang pernah tersandung kasus korupsi, kembali terpilih memenangkan kontestasi di wilayah yang sama. Kenyataan ini mengindikasikan bahwa ternyata masyarakat masih terlalu 
permisif terhadap kepala daerah yang terlibat korupsi.

Masih hangat dalam ingatan kita, terkait dengan kasus suap yang melibatkan salah satu anggota Komisi Pemilihan Umum (KPU) Republik Indonesia atas kasus dugaan penerimaan hadiah/janji terkait dengan proses pergantian antar waktu anggota DPR RI di bulan Januari 2020 lalu. Dari kronologis kasus yang terjadi, tidak bisa dipungkiri bahwa ternyata aktor utama dugaan suap juga adalah perilaku koruptif partai politik. Hal ini sudah seharusnya menjadi kehatihatian bagi 270 daerah yang akan menyelenggarakan pilkada serentak Tahun 2020.

\section{METODE PENELITIAN}

Penelitian yang digunakan dalam tulisan ini adalah penelitian dengan metode Yuridis Normatif (Legal Research) yaitu dengan cara meneliti bahan pustaka atau data sekunder. Dalam penulisan ini digunakan Pendekatan Konseptual (Conseptual Approach) melihat berbagai konsep dan kebijakan terkait dengan permasalahan yang diangkat dalam penulisan ini. Bahan hukum yang digunakan dalam penulisan ini adalah bahan hukum primer, sekunder, dan bahan hukum tersier. Bahan-bahan hukum itu kemudian disusun secara sistematis dikaji secara mendalam untuk selanjutnya ditarik kesimpulan.

\section{PEMBAHASAN}

\section{Implikasi Pilkada Langsung terhadap}

\section{Korupsi di Indonesia}

\section{a. Biaya Dalam Pemilihan Kepala} Daerah

Dalam ketentuan tersebut,
pembentuk undang-undang tidak
mengklasifikasikan antara CAKADA yang ingin menduduki kursi kepala daerah untuk kedua kalinya dan CAKADA pe-mula. Bagi CAKADA kategori pertama, maka dalam mengkondisikan dirinya agar terpilih kembali, sejak awal (sebelum menjadi calon) telah melakukan kampanye tidak kentara, karena diselubungi dengan kunjungan kerja ke daerah-daerah yang menggunakan fasilitas kedinasan untuk kepentingan pribadi.

Selain itu berbagai biaya politik yang harus ditanggung oleh pasangan calon kepala daerah komponennya lebih banyak dan tentunya menghabiskan dana yang cukup besar. Biaya politik yang harus dikeluarkan antara lain; 1) biaya pembelian "perahu", 2) biaya survei dan konsultan politik, 3) biaya kampanye terbuka dan tertutup, 4) biaya operasional tim sukses/relawan 
untuk lebih menajamkan pemahaman tentang biaya politik yang harus ditanggung pasangan calon kepala daerah akan diuraikan secara singkat, sehingga pembaca memiliki pemahaman yang utuh (Hollyson \& Sundari, 2015a).

1. Biaya Pembelian "Perahu"

Perahu dalam hal ini dikonsepsikan sebagai wadah berpolitik dalam hal ini Partai ,salah satu fungsi partai politik adalah proses rekrutmen untuk menyeleksi anggotanya dalam rangka menududuki jabatan-jabatan administrasi dan publik. Anggota yang direkrut adalah orang yang memiliki bakat, potensi, dan kapasitas (Handoyo, 2010). Namun sudah menjadi rahasia umum dalam perekrutan calaon kepala daerah tidak hanya berdasarkan kapasitas dan kapabilitas calon tetapi juga berdasarkan kepada seberapa besar mahar yang diberikan kepada partai pengusung.

Dalam banyak kasus partai politik tidak dalam posisi yang mencalonkan pasangan calon. Peran partai politik dalam pilkada langsung lebih pada posisi menyediakan legitimasi pencalonan, yang biasanya ditransaksikan dengan pihak-pihak yang ingin dicalonkan atau ingin mencalonkan seseorang menjadi calon kepala daerah. Proses ini kerap dipresentasikan dengan istilah "beli perahu" yang artinya membeli formalitas partai politik atau istilah "beli tiket" yang artinya memberi tiket pencalonan.

Proses pencalonan ini dimanfaatkan oleh sebagian elite partai politik sebagai ajang bisnis dengan memasang tarif tertentu bagi kandidat yang akan memakai partainya untuk maju dalam proses pencalonan. Nilai uang diperkirakan ratusan juta hingga miliaran rupiah, tergantung hasil negosiasi dan kesepakatan antara para kandidat dan partai atau gabungan partai, serta juga wilayah pilkada, apakah merupakan daerah potensial secara ekonomi atau daerah minus (Hanafi, 2016). Dalam bahasanya Prof Saldi Isra, partai politik telah menjadi semacam "pukat Harimau". Artinya partai politik bisa menjadi mesin uang. Begitu proses pencalonan selesai, partai politik bisa meraup uang dari mereka yang berminat. Mirip dengan pukat Harimau, jumlah uang yang diraup juga bervariasi, mulai dari ratusan juta 
rupiah sampai dengan tawaran ratusan miliar (Hanafi, 2016).

Seperti testimoni dari Slamet Kirbiyantoro yang memberikan Rp. 1,5 miliar dan Djasri Marin memberikan Rp. 2 miliar kepada PDIP. Contoh lain, dengan mengutip pemberitaan Kompas, Haboddin mencatat, bahwa seorang fungsionaris partai politik besar pernah menceritakan bagaimana untuk menjalin koalisi antar partai politik saja diperlukan "mahar" miliaran rupiah. Seorang fungsionaris partai politik besar lainnya juga pernah diminta melupakan keinginan menjadi gubernur jika "hanya" membawa Rp. 3 miliar. Pernyataan sang fungsionaris ini patut dicatat sebagai penilaian betapa leluasanya elite dan pengurus partai politik menjaring uang setoran supaya partainya bisa digunakan sebagai "perahu" sang calon untuk maju dalam pilkada langsung.

Besar kecilnya uang "perahu "ditentukan oleh banyak faktor, diantaranya: tingkat elektabilitas pasangan calon, kemampuan melakukan lobi-lobi politik, kenggotaan di partai politik dan kebijakan Pimpinan partai politik. Melihat persyaratan ini, maka belum tentu partai politik atau gabungan parpol akan mencalonkan kaderrnya sendiri untuk melaksanakan fungsi kepartaian. Sebut saja misalnya pilkada DKI jakarta yang digelar tahun 2017 lalu, dari ketiga pasangan calon yang sudah didaftarkan ketiga calon bukan kader partai pengusung.

Uang "perahu" menjadi salah satu faktor terpenting dalam penentuan calon kepala daerah melalui partai politik. Mahar politik yang nominalnya tidak sedikit ini biasanya akan dipergunakan untuk operasional partai dalam rangka pemenangan calon yang diusung. Semakin besar nilai uang "perahu" yang disanggupi oleh calon, maka semakin besar peluangnya untuk maju jadi calon kepala daerah dari partai tersebut.

2. Biaya Survei dan Konsultan Politik

Survei elektabilitas calon kepala daerah sudah menjadi suatu tren bahkan suatu keharusan dan dijadikan senjata ampuh bagi sang calon dalam setiap pemilihan kepala daerah. Dengan berpedoman pada hasil survei dapat diputuskan apakah sang calon layak atau tidak untuk dijagokan. 
Biaya politik untuk keperluan survei ditanggung oleh calon, yang nominalnya bisa mencapai miliaran rupiah. Sebagai contoh Wali Kota Makassar Ilham Arief Sirajuddin, misalnya, mengaku menyewa lembaga survei untuk memetakan dukungan. lham menyewa Lembaga Survei Indonesia, Selama setahun, tim LSI menggelar survei sebanyak 3-4 kali. "Nilai totalnya mencapai Rp 1 miliar," seorang, yang pernah menjadi calon wakil gubernur di Jawa Barat mengatakan, membutuhkan dana minimal Rp 3 miliar untuk paket lembaga survei plus konsultan. Kontrak itu biasanya dilakukan selama dua tahun, dengan termin tiga kali per enam bulan dan dua kali per tiga bulan. "Selama itu, ada 3-5 survei (Tempo news, 2020).

Selain menggelar survei calon kepala daerah juga menggunakan jasa konsultan politik. Untuk tarif sekali konsultasi bisa dikenai Rp 500 - 800 juta untuk jenis layanan semisal strategi komunikasi plus saran untuk membuat citra kandidat meningkat. Ongkos ini akan menjadi satu paket dari pemilihan slogan, penentuan foto, hingga warna khas yang akan diusung (Hollyson \& Sundari, 2015).

3. Biaya Kampanye Terbuka dan Tertutup

Kampanye rermanfaat
untuk meningkatkan elektabilitas,
menunjukan (Show) kepada
masyarakat dan pesaingnya bahwa pasangan calon tersebut mempunyai dukungan masa yang cukup besar. Hadirnya orang-orang yang menawarkan jasa untuk pengerahan masa merupakan fenomena yang muncul sebagai konsekuensi pelaksanaan kampanye pilkada langsung. Jika penyedia jasa menghargai 1 orang sebesar Rp. 50.000., maka jika kontestan menghadirkan 1000 orang maka biaya yang harus dikeluarkan sekitar Rp. 50.000.000, Jika kampanye dilaksanakan 5 kali maka biaya yang harus dikeluarkan mencapai $\mathrm{Rp}$. 250.000.000. Menurut Sekretaris Jenderal Partai Persatuan Pembangunan (PPP), Arsul Sani, biaya kampanye Pilkada DKI diperkirakan bisa mencapai Rp100 miliar.

4. Biaya Operasional Tim Sukses/Relawan.

Untuk relawan relatif tidak 
memelukan biaya yang relatif besar. Sesuai dengan namanya relawan lebih merupakan simpatisan yang bergerak secara mandiri untuk mendudkung dn menenangkan salah satu pasangan calon yang mereka dukung. Relawan biasanya membutuhkan biaya untuk pembuatan dan operasional posko, konsumsi dan operasional lapangan. Sumber biaya operasional kegiatan relawan dapat bersumber dari pasangan calon ataupun dana mandiri yang dikumpulkan sendiri oleh para relawan.

Berbeda dengan relawan, tim sukses lebih mengandalkan dana yang berasal dari pasangan calon atau dana yang dikumpulkan dari donatur pendukung pasangan calon kepala daerah untuk operasionalnya.

\section{b. Upaya Melawan Korupsi Dalam Pilkada Langsung}

Jika melihat berbagai peluang munculnya Korupsi dari pelaksanaan Pilkada langsung sebagaimana telah diuraikan di atas maka tentu perlu berbagai antisipasi yang patut dilakukan terutama bagi Pemerintah dan berbagai lembaga penyelenggara Pemilu tersebut. Beberapa hal yang kirannya menjadi catatan penting agar pelaksanaan Pilkada Langsung dapat berjalan sebagaiamana mestinya dan dijadikan sebagai wadah pengejawantahan demokrasi di Indonesia yaitu :

1. Komitmen dan integritas menjadi poin penting yang perlu dijaga dengan baik oleh jajaran penyelenggara pemilu di tingkat pusat maupun daerah. Sebuah bangsa baru dikatakan beradab jika bangsa itu mampu menjaga nilai etika, moral dan integritasnya. Dalam hal ini, KPU juga berkewajiban untuk mengumumkan siapa kepala daerah yang pernah tersangkut kasus korupsi, agar masyarakat mengetahuinya. Sehingga diharapkan masyarakat dapat menilai secara langsung kandidat pilihannya (Hayati, 2020)

2. Hal kedua apabila memang ternyata diindikasi terjadi adanya suap atau mahar dalam tahapan pencalonan dan Bawaslu kesulitan untuk pemenuhan syarat formil materil karena wewenangnya juga terbatas, maka KPK perlu hadir dan dilibatkan untuk mengungkap kasus yang terjadi. Usut tuntas perkara yang menjadi cikal bakal korupsi sampai ke akar - akarnya. Tindak dengan tegas sesuai aturan yang berlaku, siapapun itu tanpa pandang 
bulu. Jangan hanya unsur pemberi dan penerima saja yang ditindak, sementara dalangnya dilindungi, itu sama dengan tidak menyelesaikan persoalan. Dewan pengawas pun harus dapat kooperatif, bersinergi dan saling bergandengan tangan dengan satu tujuan pemberantasan Korupsi.

3. Penguatan komitmen juga perlu dilakukan oleh Partai Politik. Maraknya kasus korupsi yang terjadi mengindikasikan komitmen pemberantasan korupsi yang digaungkan oleh partai politik hanya sebatas retorikae belaka. Sikap koruptif di internal partai menjadi salah satu persoalan yang harus pula dibenahi. Diakui atau tidak bahwa kehadiran partai politik dalam suatu negara demokrasi adalah sebuah keniscayaan. Proses demokrasi tidak mungkin eksis tanpa partai politik dan sistem kepartaian tersebut. Sesuai dengan amanat Undang-Undang Nomor 7 Tahun 2017 tentang Pemilu, partai politik harus memiliki sistem seleksi dan rekrutmen keanggotaan yang memadai serta mengembangkan sistem pengkaderan dan kepemimpinan politik yang kuat. Partai harus mampu memaksimalkan fungsinya baik itu terhadap negara maupun fungsi partai politik terhadap rakyat melalui pendidikan politik dan pengkaderan serta rekrutmen politik yang efektif untuk menghasilkan kader-kader calon pemimpin yang memiliki kemampuan di bidang politik. Memasuki tahapan pilkada serentak 2020, partai politik wajib berkomitmen untuk tidak menetapkan dan menerima mahar calon kepala daerah yang akan maju di pencalonan. Silakan cari kader partai yang mumpuni dan berintegritas berasal dari domisili setempat untuk dicalonkan secara demokratis dan terbuka. Pemilihan kepala daerah secara langsung (Pilkada) 2005, telah menanamkan bibit pemerintahan yang tidak steril dari praktik korupsi. Untuk itu, keberlangsungan Pilkada tersebut perlu dipertanyakan atau ditinjau kembali kemanfaatannya bagi kepentingan nasional. Jika tidak, upaya pemberantasan tin-dak pidana korupsi yang tengah digalakkan saat ini, hanya akan menjadi suatu cita-cita. Karena ibarat di satu sisi ingin membersihkan kotoran, tapi di sisi lain kotoran baru muncul kembali. 
Hal ini menjadi penting agar dapat menekan angka korupsi bukan membuka celah korupsi.

4. Masyarakat harus lebih berhati-hati dalam menggunakan hak pilihnya di Pilkada serentak Tahun 2020. Praktik politik uang (Money Politic) pada masa kampanye sampai dengan masa tenang pada saat sekarang akan senantiasa dilakukan calon kepala daerah untuk mendulang suara. Masyarakat juga akan menjadi terkotak-kotak dengan banyaknya partai politik, kemungkinan dan hampir pasti calon pasangan atau melalui parpol pengusung dan tim kampanyenya akan berusaha keras untuk dapat mempengaruhi calon pemilih dengan suatu janji atau iming-iming tertentu. Dalam kondisi masyarakat yang masih dalam proses berdemokrasi dan persoalan ekonomi yang masih menghimpit kehidupan, cara mem- pengaruhi pemilih melalui pemberian uang ada- lah suatu hal yang sulit dihindari, karena dalam menentukan pilihan bukan berdasar asas Jujur 'hati nurani', tetapi lebih didasarkan pada nilai untung rugi dan lebih lagi untuk dapat menopang kebutuhan kehidupan terutama pada saat pandemi Covid 19 ini.

5. Konsep Pilkada Asimetris Pilkada asimetris dalam hal ini ialah pelaksanaan pilkada yang didasarkan pada kedewasaan demokrasi tiap daerah mungkin dapat dilakukan kajian mendalam. Bagi daerah yang dianggap mengerti demokrasi, pilkada langsung mungkin bisa diterapkan. Namun, jika di daerah tersebut penduduknya belum memiliki kedewasaan demokrasi yang mumpuni berdasarkan hasil penelitian maupun riset yang dapat digagas sebagai upaya menuju ke dalam pilkada yang demokrats. Pilkada dapat digelar secara tidak langsung. Hal ini dapat dilihat pada contoh pelaksanaan Pilkades yang telah banyak diterapkan dengan sistem $e$-vote yang telah pula mulai dilakukan di beberapa daerah sebagai bagian dari adaptasi perkembangan zaman dan pelibatan teknologi dalam konteks Pemilu.

\section{PENUTUP}

Pilkada langsung merupakan bagian penting dari proses panjang perjalanan Indonesia menuju kedewasaan berdemokrasi, dengan Demokrasi langsung 
pula negara Indonesia belajar memaknai demokrasi tidak hanya sekedar memilih dan dipilih oleh rakyat, namun proses panjang sebagai bagian dari upaya menuju ke demokrasi yang hakiki sebagaimana pilihan terbaik dari sistem pemerintahan yang lain di belahan bumi ini tentu diharapkan tidak hanya selesai pada proses Pilkada itu saja namun banyak hal lain yang kiranya perlu dilakukan termasuk memastikan bahwa Korupsi tidak serta merta menjelma dalam proses dan bahkan akhir dari Pilkada itu. Terdapat korelasi antara pemilukada langsung dengan perilaku korupsi. Terjeratnya ratusan kepala daerah dalam kasus korupsi diduga politk biaya tinggi, baik untuk pencalonan lewat partai politik, biaya kampanye yang tidak terawasi dengan baik sehingga tanpa batas, dan adanya politik uang langsung kepada pemilih, memicu kepala daerah berusaha mengembalikan modal sehingga memunculkan istilah adanya industri politik. Perlu berbagai upaya dan perbaikan dari sistem di Negara ini,seperti halnya yang dikemukakan oleh Lawrence Friedman bahwa menegakan hukum haruslah dilakukan dengan bersama-sama oleh ketiga unsur di dalam Negara, Substansi Hukum termasuk di dalamnya berbagai perubahan dan perbaikan dalam setiap perundang-undangan khususnya Pemilu, Struktur Hukum yang terkait dengan berbagai pelaksana ketentuan hukum dan berbagai lembaga di dalamnya terutama kaitan dengan Pemilu langsung dan terakhir Kultur Hukum berkaitan dengan respon masyarakat terhadap berbagai aturan hukum misalnya kepatuhan dan kedewasaan masyarakat dalam berdemokrasi terutama dalam mendukung Pemilu yang Langsung Umum Bebas Rahasia serta Jujur dan Adil. Ketiga hal ini menjadi bagian penting sebagai upaya mencegah menyebarluasnya virus Korupsi dalam pelaksanaan Pilkada langsung di Indonesia.

\section{DAFTAR RUJUKAN}

Dennis, R., Nellis John, R., \& Shabbir, C. (1984). Decentralization in Developing Countries: A Review of Recent Experience. World Bank, Washington, $D C$.

Hamzah, A. (2014). Pemberantasan Korupsi Melalui Hukum Pidana Nasional dan Internasional, Jakarta: PT. Raja Grafindo Persada.

Hanafi, R. I. (2016). Pemilihan Langsung Kepala Daerah di Indonesia: Beberapa Catatan Kritis untuk Partai Politik. Jurnal Penelitian Politik, 11(2), 16.

Handoyo, E. (2010). Pancasila Dalam Perspektif Kefilsafatan Dan Praksis. Jogjakarta: Ar-Ruzz Media. 
Hollyson, R., \& Sundari, S. (2015). Pilkada (Penuh Euforia, Miskin Makna). Jakarta: Bestari.

Mubarok, M. M. (2005). Suksesi Pilkada Jurus Memenangkan Pilkada Langsung. Surabaya: Java Pustaka Media Utama.

Nasional, K. H. (2014). Kebijakan Mendukung Pencegahan dan pemberantasan Tindak Pidana Korupsi. KHN RI, Cetakan Pertama Mei.

Suharto, D. G., Nurhaeni, I. D. A., Hapsari, M. I., \& Wicaksana, L. (2017). Pilkada, politik dinasti, dan korupsi. PERTEMUAN FORUM DEKAN ILMU-ILMU SOSIAL PTN SE-INDONESIA.

Zulkarnain, Z. (2010). KAJIAN PENEGAKAN HUKUM PASCA PEMILIHAN KEPALA DAERAH (Mempertanyakan Komitmen Pemenang Pilkada dalam Penegakan Hukum dan Pemberantasan Korupsi di Daerah). Jurnal Konstitusi, 3(2).

Neni Nur Hayati. 2020. https://republika.co.id/berita/q5ahe8257/k orupsi-di-pusaran-pilkada

https://m.tempo.co/read/news/ Diunduh 27 juli 2020 .

https://republika.co.id/berita/q5ahe8257/k orupsi-di-pusaran-pilkada. diakses $27 \mathrm{Juli}$ 2020 